\title{
Neonatal Host Defense Mechanisms against Listeria monocytogenes Infection: The Role of Lipopolysaccharides and Interferons
}

\author{
R. BORTOLUSSI, T. ISSEKUTZ, S. BURBRIDGE, AND H. SCHELLEKENS \\ Departments of Pediatrics and Microbiology [R.B., T.I., S.B.], Dalhousie University, Halifax, Canada, \\ and TNO Primate Center [H.S.], Rÿswÿk, The Netherlands
}

\begin{abstract}
The human newborn infant is susceptible to lethal infection caused by a number of bacterial species including Listeria monocytogenes, a gram-positive rod which is pathogenic by virtue of its ability to survive intracellularly. In adult animals interferon (IFN)- $\alpha / \beta$ and IFN- $\gamma$ or agents that induce or augment IFN production confer protection against lethal $L$. monocytogenes infection. Regulation and production of IFN is poorly understood during the neonatal period. We therefore evaluated the role of IFN- $\alpha / \beta$ and IFN- $\gamma$, IFN-inducers (polyinosinic:polycytidylic acid, amino-bromo-phenyl-pyrimidinone, aminoiodophenyl pyrimidinone) and lipopolysaccharide in modifying neonatal $L$. monocytogenes infection. Pretreatment of juvenile rats with polyinosinic:polycytidylic acid or lipopolysaccharide protected them against a lethal challenge with $L$. monocytogenes. Among newborn rats, polyinosinic: polycytidylic acid, amino-iodo-phenyl pyrimidinone and amino-bromophenyl-pyrimidinone gave significant protection, however, lipopolysaccharide did not influence survival. The role of IFN was further examined. Pretreatment of 3-d-old rats with purified IFN- $\alpha / \beta$, native rat IFN- $\gamma$ or rDNA rat IFN- $\gamma$ protected them against the lethality of subsequent $L$. monocytogenes injection. At $3 \mathrm{~d}$ after bacterial challenge, bacterial content in the spleens of 3-d-old rats pretreated with $\mathrm{rIFN}-\gamma$ were significantly decreased compared to controls: IFN- $\alpha / \beta$-pretreated animals had less of a decrease, which become significant only $5 \mathrm{~d}$ after challenge. Our experiments indicate a role for IFN in neonatal host defense against $L$. monocytogenes infection. (Pediatr Res 25:311-315, 1989)
\end{abstract}

\section{Abbreviations}

IFN, interferon

polyI/C, polyinosinic:polycytidylic acid

ABPP, amino-bromo-phenyl-pyrimidinone

AIPP, amino-iodo-phenyl-pyrimidinone

LPS, lipopolysaccharide

CFU, colony forming units of bacteria

ip, intraperitoneal

sc, subcutaneous

TNF, tumor necrosis factor

\section{Received August 12, 1988; accepted November 9, 1988}

Correspondence Dr. R. Bortolussi, Infection and Immunology Research Laboratory, Izaak Walton Killam Hospital for Children, 5850 University Avenue, Halifax, Nova Scotia, Canada B3J 3G9.

Made possible by funds provided from the Medical Research Council of Canada Grants MT 7610 and MA 8575. RB is supported by MRC development Grant DG 208.
Listeria monocytogenes, the causative agent of listeriosis, is a short gram-positive motile rod believed to be pathogenic by virtue of its ability to survive intracellularly. For adult immunocompetent animals, the process leading to development of resistance has been partially elucidated. Within 3-5 d after $L$. monocytogenes infection has been introduced, there is a rapid proliferation of reactive T-lymphocytes (1-4). Resistance to Listeria infection appears to be mediated by a T-lymphocyte-produced lymphokine which induces increased macrophage and natural killer cell activity (5-7), which then become Listericidal $(8,9)$. Interferons, peptide molecules capable of affecting a number of cellular functions, are among the major lymphokines activating these cells.

In mature animals $L$. monocytogenes infection induces circulating IFN- $\alpha / \beta$ soon after the organism is injected (10-12). Peak immunity to L. monocytogenes, which is evident on or about the 6 th $\mathrm{d}$ of infection, coincides with the production of IFN- $\gamma$ by the spleen $(4,13,14)$. Recently, Havell (13) has also shown that interferon production during $L$. monocytogenes infection is greatly augmented by LPS, and he suggested this as an explanation for the increased resistance to $L$. monocytogenes infection that is observed for animals pretreated with LPS (15).

It has recently been shown that human neonatal lymphocytes produce little IFN- $\gamma$ in response to mitogens $(16,17)$. Decreased production of IFN- $\gamma$ by neonatal cells appears to be due both to intrinsic capacity to produce IFN- and to regulatory mechanisms $(16,17)$. In addition, neonatal monocytes and monocyte-derived macrophages, important target cells for IFN- $\gamma$, are less active than adult cells $(18,19)$.

The human neonate is unusually susceptible to infection with $L$. monocytogenes. The reason for this is not clear. Because of the role of IFN and LPS in modifying adult $L$. monocytogenes infection, we investigated the effects of LPS, IFN, and IFNinducers in the development of resistance to L. monocytogenes using a newborn rat model of neonatal infection $(20,21)$. Our studies support an important role for IFN- $\alpha / \beta$ and IFN- $\gamma$ in newborn $L$. monocytogenes infection and also demonstrate a deficiency for newborn animals to respond to LPS.

\section{MATERIALS AND METHODS}

Reagents. LPS was obtained from Difco Laboratories (Detroit, MI). PolyI/C was obtained from P.L. Biochemicals Inc. (Rochester, NY). ABPP and AIPP were kindly provided by Upjohn Company (Kalamazoo, MI). Rat IFN $-\alpha / \beta$ was purchased from Lee Biologics (San Diego, CA). Rat rIFN- $\gamma$ is the product of transfection with a plasmid carrying the chromosomal rat IFN$\gamma$ gene as described elsewhere (22). The rIFN- $\gamma$ was purified to $>98 \%$ purity by immunoaffinity chromatography using MAb bound to sepharose. Native rat IFN- $\gamma$ was produced as described elsewhere by treating rat lymphocytes from lymph nodes and 
spleen with neuraminidase and galactose oxidase (23). The cells were then incubated for $48 \mathrm{~h}$, and the cultured supernatant was purified by hydroxylappatite chromatography to a sp act of $>500000 \mathrm{U} / \mathrm{mg}$.

LPS (O55:B5) was mixed with PBS to a concentration of 1 $\mathrm{mg} / \mathrm{mL}$, and this stock was stored in aliquots at $-20^{\circ} \mathrm{C}$. Stock aliquots were diluted $1 / 100-1 / 1000$ for animal inoculation. PolyI/C was solubilized in PBS by heating a $2 \mathrm{mg} / \mathrm{mL}$ mixture to $50^{\circ} \mathrm{C}$ for $15-20 \mathrm{~min}$ or until the solution clarified. Stock solution was diluted in PBS for injection into animals. ABPP and AIPP were prepared using sterile preservative-free $0.5 \%$ methyl cellulose $(2500 \mu \mathrm{g} / \mathrm{ml})$. The material was sonicated for 1-2 min to distribute the drug throughout the methyl cellulose. Fresh dilutions in methyl cellulose were prepared for each treatment. Rat IFN- $\alpha / \beta$ was stored at $4^{\circ} \mathrm{C}$ in aliquots, then diluted in sterile PBS for injection. Rat IFN- $\gamma$ was stored at $-70^{\circ} \mathrm{C}$ in aliquots, then diluted in PBS with $0.5 \%$ BSA (PBS-BSA) for injection into animals. Controls used for each preparation were injected with identical vehicles which lacked the active agent.

Bacteria. A strain of $L$. monocytogenes type $4 \mathrm{~b}$ designated $15 \mathrm{U}$ in previous publications $(20,21)$ and isolated originally from the blood of an infant with neonatal listeriosis was used in these studies. Aliquots of a stock culture were stored in $20 \%$ glycerol and frozen at $-20^{\circ} \mathrm{C}$ until required for animal studies. A portion of the frozen aliquot was inoculated into brain heart infusion broth (Difco) and incubated at $37^{\circ} \mathrm{C}$ overnight. The organism was then sedimented $(3000 \times g$ for $10 \mathrm{~min})$ and washed once in PBS. The number of bacteria was estimated spectrophotometrically and verified using pour plate technique.

In vivo studies. Timed pregnant outbred Sprague-Dawley rats (Canadian Hybrid Farms, Hall's Harbour, Nova Scotia, Canada) were obtained at the 13th $\mathrm{d}$ of gestation and fed rat food ad lib and housed in a controlled environment $(16 \mathrm{~h}$ light/d) until parturition (usually 21 st-22nd d of gestation). Pups that were 3d-old or 30-d-old were randomly allocated to receive one of the treatment regimes. To minimize inter-litter variability, no more than three animals in each litter received the same treatment regime. Rats that were 3-d-old were injected with $10^{6} \mathrm{CFU}$ of $L$. monocytogenes ip or with $10^{8} \mathrm{CFU}$ subcutaneously, an inoculum that killed approximately $90 \%$ of untreated animals. Most deaths occurred 2-5 d after bacterial challenge. Animals that were 30d-old were injected with $10^{9} \mathrm{CFU}$ of $L$. monocytogenes ip, an inoculum that caused $50 \%$ mortality. A larger inoculum in 30$\mathrm{d}$-old rats resulted in overwhelming bacterial infection and deaths within $48 \mathrm{~h}$ of injection. The dose of $10^{9}$ was chosen to simulate the dynamics of infection better in 3-d-old rats in which deaths occur on d 3 or 4 after challenge. In some experiments, blood cultures were obtained by cardiac puncture at the time the animal was killed by carbon dioxide inhalation. Quantitation of blood bacterial content was done using pour plates of serial dilutions of blood. Results were expressed as CFU/mL of blood. In some animals, the spleen was dissected free, weighed, and homogenized in PBS. Pour plates were prepared using serial dilutions from the splenic homogenates and bacterial content expressed as CFU/ $100 \mathrm{mg}$ of spleen. Pour plates of tissue used brain heart infusion agar (Difco) containing $3 \mu \mathrm{g} / \mathrm{mL}$ moxolactam (Lilly Pharmaceutical, Toronto, Canada) to suppress any contaminating bacteria. This level of antibiotic did not affect $L$. monocytogenes viability.

Statistical methods. Analysis of groups was done using a 2sided paired $t$ test for comparison of bacteria in tissue. A chisquare test or the Fisher exact test were used to compare survival of various groups. Significance was accepted for $p<0.05$.

\section{RESULTS}

As shown in Figure 1, pretreatment of juvenile rats with polyl/ $\mathrm{C}(50 \mu \mathrm{g} / \mathrm{kg}$ body wt) given ip 2 and $1 \mathrm{~d}$ before and on the $\mathrm{d}$ of bacterial challenge or LPS $(20 \mu \mathrm{g} / \mathrm{kg}$ body wt) given sc $1 \mathrm{~d}$ before challenge significantly improved the animals' survival calculated

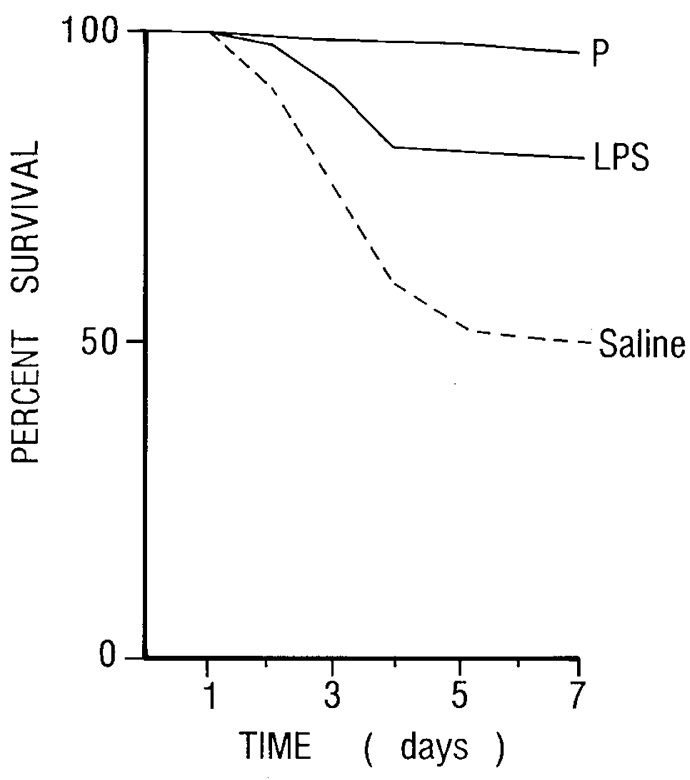

Fig. 1. Survival of 30-d-old animals after $L$. monocytogenes injection. The percentage of survival of 30-d-old animals for $7 \mathrm{~d}$ after ip injection of $1 \times 10^{9} \mathrm{CFU}$ L. monocytogenes is shown. Animals had been pretreated ip with polyl $/ \mathrm{C}(\mathrm{P}, 50 \mu \mathrm{g} / \mathrm{kg}$ body wt) or sc with LPS $(20 \mu \mathrm{g} / \mathrm{kg}$ body wt); $p<0.001$ and $p<0.005$ for polyI/C and LPS versus saline, respectively.

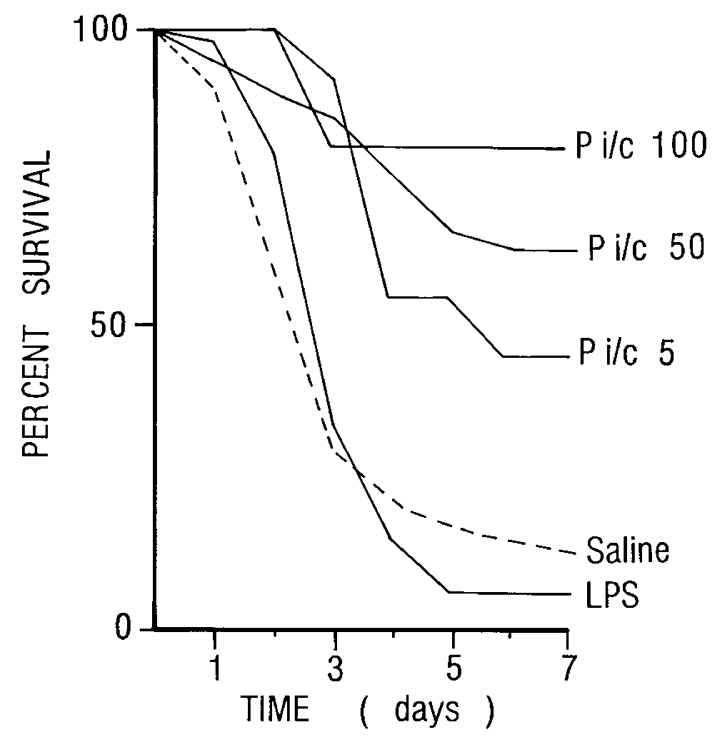

Fig. 2. Survival after ip injection with $L$. monocytogenes in 3-d-old (newborn) rats. Newborn rats that had been pretreated ip with polyI/C (Pi/c 100, 50 or $5 \mu \mathrm{g} / \mathrm{kg}$ of body wt), sc with LPS (L, $20 \mu \mathrm{g} / \mathrm{kg}$ body wt), or PBS (saline) were injected ip on day 3 of life with $10^{6}$ CFU of $L$. monocytogenes. The percentage survival was calculated for $7 \mathrm{~d}$ after bacterial challenge. $p<0.001$ for polyl $/ \mathrm{C} 50$ and $100 \mu \mathrm{g} / \mathrm{kg}$ versus saline and $p<0.05$ for polyI/C $5 \mu \mathrm{g}$ versus saline.

$7 \mathrm{~d}$ after injection ( $p<0.001$ and $p<0.005$, respectively). Among newborn animals (Fig. 2), the effects of polyI/C (50 $\mu \mathrm{g} /$ $\mathrm{kg}$ body $\mathrm{wt})$ were similar to those seen with juveniles $(p<0.001$ versus controls). A dose-related response to polyl/C was shown for doses of $5-100 \mu \mathrm{g} / \mathrm{kg}$ animal wt. In addition, a protective effect of polyI/C was observed when bacteria and polyI/C were administered at different sites (Table 1). However, unlike the juvenile animals, 3-d-old pups had no protective effect from LPS (Fig. 1). No benefit was observed for higher or lower doses of 
Table 1. Effect of various agents on survival of intraperitoneally L. monocytogenes-infected newborn rats

\begin{tabular}{|c|c|c|c|}
\hline \multirow[b]{2}{*}{ Agent* } & \multirow[b]{2}{*}{$\begin{array}{l}\text { Route of } \\
\text { treatment }\end{array}$} & $\begin{array}{l}\text { Treatment } \\
\text { group }\end{array}$ & \multirow{2}{*}{$\begin{array}{c}\text { Controls } \\
\begin{array}{c}\text { No.: surviving/ } \\
\text { injected } \\
\text { (\% survival) }\end{array}\end{array}$} \\
\hline & & $\begin{array}{l}\text { No.: surviving/ } \\
\text { injected } \\
\text { (\% survival) }\end{array}$ & \\
\hline \multicolumn{4}{|l|}{ Poly I/C } \\
\hline $50 \mu \mathrm{g} / \mathrm{kg}$ & ip & $35 / 55(64) \dagger$ & $12 / 93(13)$ \\
\hline $50 \mu \mathrm{g} / \mathrm{kg}$ & $\mathrm{sc}$ & $7 / 33(21)$ & $7 / 56(12)$ \\
\hline $500 \mu \mathrm{g} / \mathrm{kg}$ & $\mathrm{sc}$ & $9 / 10(90) \dagger$ & $7 / 56(12)$ \\
\hline \multicolumn{4}{|l|}{$\mathrm{ABPP}$} \\
\hline $2.5 \mathrm{mg} / \mathrm{kg}$ & ip & $4 / 20(20)$ & $1 / 17(6)$ \\
\hline $1.25 \mathrm{mg} / \mathrm{kg}$ & po & $6 / 10(60) \ddagger$ & $2 / 14(14)$ \\
\hline \multicolumn{4}{|l|}{ AIPP } \\
\hline $2.5 \mathrm{mg} / \mathrm{kg}$ & ip & $10 / 19(53) \dagger$ & $1 / 17(6)$ \\
\hline $1.25 \mathrm{mg} / \mathrm{kg}$ & po & $2 / 10(20)$ & $2 / 14(14)$ \\
\hline \multicolumn{4}{|l|}{ LPS } \\
\hline $20 \mu \mathrm{g} / \mathrm{kg}$ & sc & $3 / 52(6)$ & $7 / 56(12)$ \\
\hline
\end{tabular}

* Except for LPS, all agents were injected ip on $\mathrm{d} 2$ and 1 before and the $\mathrm{d}$ of bacterial challenge. For LPS, animals were injected $\mathrm{sc} 1 \mathrm{~d}$ before bacterial challenge.

$\dagger p<0.01$ versus control, chi-square test or Fisher exact test if groups less than 20 .

$\ddagger p<0.05$ versus control, Fisher exact test.
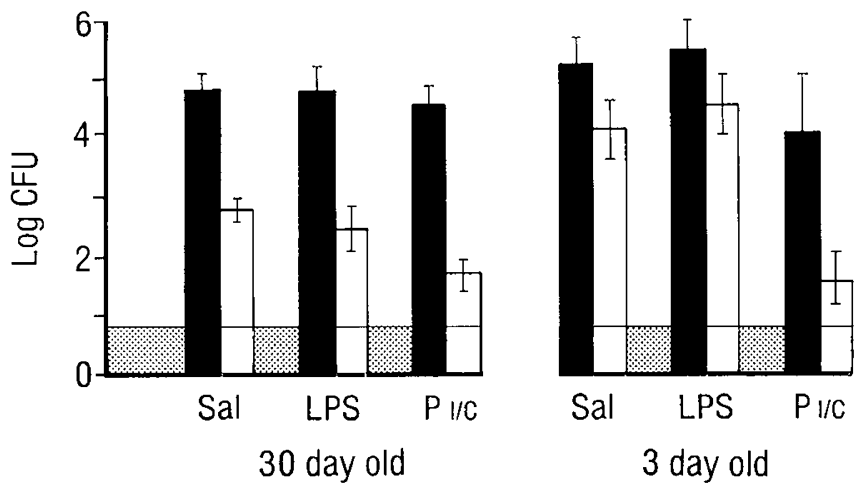

Fig. 3. Splenic and blood L. monocytogenes concentration. Mean log CFU \pm SEM in spleen (per $100 \mathrm{mg}$ tissue, solid bars) or in blood (per $\mathrm{ml}$ blood, open bars) for 30-d-old and 3-d-old rats pretreated with PBS (Sal), LPS, or polyI/C (PI/C). Cultures were obtained $3 \mathrm{~d}$ after bacterial challenge. Stippled area shows the limit of sensitivity for the assay.
LPS or of bacteria (Bortulossi R, Issekutz T, Burbridge S, Schellekens $\mathrm{H}$, manuscript in preparation).

The results of quantitative cultures of splenic tissue and blood obtained $3 \mathrm{~d}$ after bacterial challenge from juvenile and newborn animals are shown in Figure 3. The geometric mean bacterial content in spleens was similar for 30-d-old and 3-d-old animals. In both age groups, animals pretreated with polyI/C had a lower content of bacteria. In contrast to this, a marked difference in the bacterial content of blood was found for the two age groups. The 3-d-old animals treated with PBS or LPS had higher bacterial content in blood. Animals pretreated with polyl/C had a lower content of bacteria in blood, in a range similar to that found in older animals.

Other IFN-inducers (ABPP and AIPP) suspended in methyl cellulose $(2500 \mu \mathrm{g} / \mathrm{ml})$, were assessed using, as control, animals treated with the same carrier without the active agent. Animals that were 3 -d-old were injected ip with $0.1 \mathrm{~mL}(250 \mu \mathrm{g})$ or were fed approximately $0.05 \mathrm{~mL}(125 \mu \mathrm{g})$ of the compounds three times in total, 2 and $1 \mathrm{~d}$ before and on the $\mathrm{d}$ of bacterial challenge. As shown in Table 1, the survival of animals fed ABPP was $60 \%$ compared to $14 \%$ for controls $(p<0.05)$; survival for animals fed AIPP was $20 \%$ ( $p>0.05$ versus control animals). When animals were given the drugs ip, AIPP was more effective in preventing death than ABPP (53\% versus $20 \%$ survival, Table 1).

In subsequent experiments, purified IFN $-\alpha / \beta$ and native rat IFN- $\gamma$ were administered ip using the same schedule for inoculation as with polyI/C. Both IFN- $\gamma$ and IFN $-\alpha / \beta$ were found to be protective in newborn rats in a dose-related fashion. IFN $\left(10^{5}\right.$ $\mathrm{U} / \mathrm{kg}$ ) of either type were protective (Table 2 ).

The dynamics of IFN-induced protection of $L$. monocytogenes-infected newborn pups were studied further by killing animals and determining the bacterial burden in spleen $1,3,5$, or $7 \mathrm{~d}$ after they had been inoculated with an $\mathrm{LD}_{25}$ dose of bacteria. Rat rIFN- $\gamma$ was used in these studies in place of native rat IFN- $\gamma$. The bacterial content in the spleens at 1,3 , and $5 \mathrm{~d}$ was significantly decreased for animals receiving rIFN- $\gamma$; animals receiving IFN- $\alpha / \beta$ were not significantly different from controls until $\mathrm{d} 5$. In addition, the number of injections appears to correlate with the clearance of bacteria from spleen. The geometric mean CFU in spleens increased as the number of IFN injections decreased (see Table 3).

\section{DISCUSSION}

At least three stages of host response to Listeria occur in normal adult animals (24). Within hours after intravenous injection of organisms, the liver and spleen capture and destroy $50 \%$ to $90 \%$

Table 2. Effect of IFN on survival of L. monocytogenes-infected newborn rats

\begin{tabular}{|c|c|c|c|c|c|}
\hline & & & & Treatment groups & Controls \\
\hline $\begin{array}{l}\text { IFN } \\
\text { type* }\end{array}$ & $\mathrm{U} / \mathrm{kg}$ & $\begin{array}{l}\text { Treatment } \\
\text { route* }\end{array}$ & $\begin{array}{c}\text { Challenge } \\
\text { route } \dagger\end{array}$ & $\begin{array}{c}\text { No.: surviving/injected } \\
\text { (\% survival) }\end{array}$ & $\begin{array}{c}\text { No.: surviving/injected } \\
\text { (\% survival) }\end{array}$ \\
\hline \multirow{3}{*}{$\alpha / \beta$} & $10^{5}$ & ip & ip & $10 / 10(100) \ddagger$ & $3 / 18(17)$ \\
\hline & $10^{3}$ & ip & ip & $10 / 19(53) \S$ & $3 / 18(17)$ \\
\hline & $10^{5}$ & ip & sc & $1 / 7(14) \|$ & $0 / 6(0)$ \\
\hline \multirow[t]{3}{*}{$\gamma$} & $10^{5}$ & ip & ip & $10 / 10(100) \$$ & $3 / 18(17)$ \\
\hline & $10^{3}$ & ip & ip & $2 / 10(20)$ & $3 / 18(17)$ \\
\hline & $10^{5}$ & ip & $\mathrm{sc}$ & $6 / 7(86)$ & $0 / 6(0)$ \\
\hline
\end{tabular}

* IFN- $\alpha / \beta$ or IFN- $\gamma$ were injected by the route indicated on $\mathrm{d} 2$ and 1 before and the $\mathrm{d}$ of bacterial challenge.

$\dagger 10^{6} \mathrm{CFU} L$. monocytogenes were injected either ip or $10^{8} \mathrm{CFU}$ were injected sc.

$\ddagger p<0.01$ versus control (Fisher exact test).

$\S p<0.05$ versus control (Fisher exact test).

$\| p<0.05$ versus IFN- $\gamma$ (Fisher exact test).

If $p<0.05$ versus IFN- $\alpha / \beta$ and versus controls (Fisher exact test). 
Table 3. Effect of number of IFN doses on bacterial content in spleen

\begin{tabular}{ccc}
\hline \multirow{2}{*}{$\begin{array}{c}\text { No. treatment } \\
\text { doses* }\end{array}$} & \multicolumn{2}{c}{$\mathrm{CFU} / 100 \mathrm{mg}$ spleen } \\
\cline { 2 - 3 } & \multicolumn{1}{c}{$\mathrm{IFN}-\gamma \dagger$} & $\mathrm{IFN}-\alpha / \beta \ddagger$ \\
\hline 3 & $1.6 \times 10^{2}$ & $5.6 \times 10^{4}$ \\
2 & $10.9 \times 10^{2}$ & $9.3 \times 10^{4}$ \\
1 & $32.4 \times 10^{2}$ & $17.8 \times 10^{4}$ \\
\hline
\end{tabular}

* Animals were injected ip 3 times (on $\mathrm{d} 2$ and 1 before and on the $\mathrm{d}$ of bacterial challenge), 2 times (and 1 before and on the $\mathrm{d}$ of bacterial challenge), or 1 time (on the $\mathrm{d}$ of bacterial challenge).

$\uparrow 10^{3} \mathrm{U}$ IFN $-\gamma$ was injected ip on the $\mathrm{d}$ indicated, and the geometric mean of bacteria in spleen was counted for four animals in each group that were killed $3 \mathrm{~d}$ after bacterial challenge.

$\ddagger 10^{3} \mathrm{U}$ IFN- $\alpha / \beta$ was injected ip on the $d$ indicated, and the geometric mean of bacteria in spleen was counted for four animals in each group that were killed $3 \mathrm{~d}$ after bacterial challenge.

of the inoculum. The surviving bacteria multiply in macrophage cells of the liver and spleen for 2 or 3 more d. In the normal mature host, specific T-cell immunity (activation) develops after this $(1-3,6,15,25)$. Once activated, immune T-cells secrete IFN- $\gamma$ and other lymphokines having immunomodulating effects $(4,7,14,23,26)$.

The role of IFN $-\alpha / \beta$ and IFN- $\gamma$ has been demonstrated for adult mice $(13,27,28)$. Mice infected intravenously with an immunizing dose of $L$. monocytogenes produced circulating IFN$\alpha / \beta$ during the inductive phase of immune response. In addition, mice acquire a 50 -fold greater capacity to produce IFN- $\alpha / \beta$ after intravenous injection of endotoxin. Finally, peritoneal exudate cells and splenic cells of mice infected with $L$. monocytogenes show increased production of IFN- $\gamma$ after antigen or mitogen stimulation. The increased production of IFN- $\gamma$ correlates with the clearance of Listeria from the peritoneal cavity and spleen. Neutralizing MAb to IFN- $\gamma$ inhibits the generation of activated macrophages in vitro (14). In vivo, MAb also abrogates clearance of bacteria from the spleen and peritoneal cavity (27).

Pretreatment of adult mice with LPS has also been demonstrated to enhance protection against death due to Listeria (15). LPS has also been shown to increase the accumulation of activated mononuclear phagocytic cells in the liver (29) and the production of TNF from monocytes (30). Because neonatal cells have intrinsic and regulatory deficiencies in IFN- $\gamma$ production $(17,26)$ and because LPS may have a synergistic modulating effect on host immunity $(13,29,30)$, we investigated these two factors in newborn immunity to $L$. monocytogenes.

Initially we demonstrated that juvenile $(30$-d-old) rats were protected from $L$. monocytogenes infection when pretreated with LPS or the IFN-inducer, polyI/C. Such animals showed significant improvement in survival and a decreased bacterial load in splenic tissue. Bacterial content in blood was relatively low in both untreated and treated juvenile animals, approximately 1 / 1000 of spleen (CFU/100 mg spleen versus CFU/mL blood). When 3-d-old rat pups were similarly pretreated, a significant protective effect was seen with polyI/C only. In contrast to older animals, LPS had no protective effect (Fig. 1). In addition, both untreated and LPS-treated animals had similar bacterial content in blood, approximately 10 -fold higher than in juvenile animals (Fig. 3). In this respect, 3-d-old polyl/C treated animals were similar to untreated juvenile animals (Fig. 3).

Other IFN inducing agents (AIPP and ABPP) were protective as well. With AIPP, protection was only demonstrated when the drug was administered at the same site as bacteria (ip), while ABPP protection was best when it was given by mouth. Oral administration of ABPP induces high levels of circulating IFN in several animal species (31). By contrast, AIPP is one of the most active antiviral agents when given ip but lacks activity when given orally (32). Overall, the results of experiments using AIPP

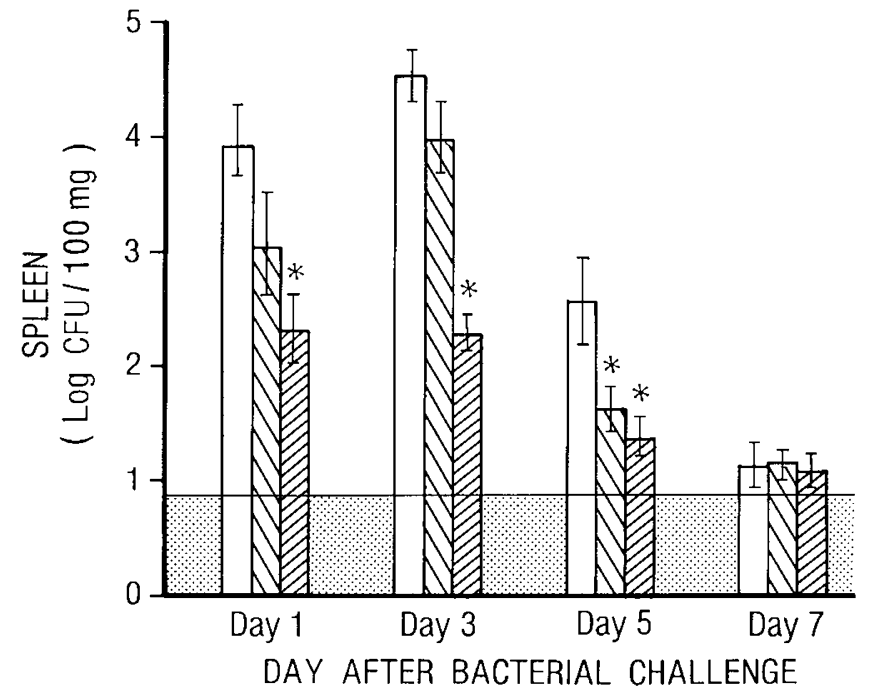

Fig. 4. Effect of interferon pretreatment on splenic concentration of L. monocytogenes. Mean $\log \mathrm{CFU} \pm \mathrm{SEM}$ in spleen (per $100 \mathrm{mg}$ tissue) for newborn rats pretreated with PBS $(\square), \mathrm{IFN}-\alpha / \beta(\mathbb{Q})$ or IFN- $\gamma(\mathbb{2})$ before challenge with bacteria. Animals were killed at different times after ip bacterial challenge. Stippled area shows the limit of sensitivity for the assay. ${ }^{*} p<0.05$ treated versus controls.

and ABPP support a role for IFN in the protection that was seen in newborn rats. However, Anthony et al. (33) have suggested that the effect of polyI/C, ABPP, and AIPP may act by non-IFN mechanisms in inducing Listeria protection. In addition, circulating IFN is found only in low concentration after these agents are administered to rats (34). To determine the importance of IFN $-\alpha / \beta$ and IFN- $\gamma$ more precisely, studies were repeated using purified rat IFN- $\alpha / \beta$, IFN- $\gamma$, and rat rIFN- $\gamma$. A dose-related protective effect was shown (Table 2 ). The dose required to give complete protection in rats was similar for IFN $-\alpha / \beta$ and $-\gamma\left(10^{5}\right.$ $\mathrm{U} / \mathrm{kg}$ ); however, only IFN- $\gamma$ was effective if bacteria were given at a different site. The maximum effects of IFN were demonstrated when it was administered on 3 consecutive d before bacterial challenge (Table 3 ). With IFN- $\gamma$, significant benefit was present within $1 \mathrm{~d}$ of bacterial challenge; benefit was not seen for IFN- $\alpha / \beta$ until $5 \mathrm{~d}$ (Fig. 4). This suggests to us that the effect of IFN- $\alpha / \beta$ may be dependent on other factor(s) that are induced or augmented by it.

Our experiments therefore further support the role for IFN- $\alpha$ / $\beta$ and $-\gamma$ in the host immune response to $L$. monocytogenes infection. Newborn rats respond to IFN-inducers, polyI/C, and $\mathrm{ABPP}$, by increasing their resistance to $L$. monocytogenes infection. The dynamics of bacterial infection in newborn rats after pretreatment with polyI/C mimics that seen among untreated juvenile animals. Although, as proposed by Anthony et al. (33), polyI/C and ABPP may have anti-Listeria activity unrelated to IFN production, our study suggests that IFN does play a role in our animal model. That this effect was related to IFN was supported by experiments using purified IFN $-\alpha / \beta$ or rat rIFN- $\gamma$. Newborn rats therefore appear to be protected by IFN against overwhelming $L$. monocytogenes infection. The role of LPS in neonatal protection against $L$. monocytogenes infection is less clear. Pretreatment of juvenile animals with LPS led to significant protection against subsequent bacterial challenge. Similar treatment of 3-d-old animals with varying doses of LPS had no effect. Recently it has been shown that newborn monocytes in culture fail to produce TNF when stimulated with LPS (30). A defect in neonatal responsiveness to LPS is therefore postulated. In adult listeriosis, LPS appears to augment the production of IFN and TNF. Both of these cytokines may have a role in host defense to Listeria. This defect in the newborn therefore may contribute to their susceptibility to Listeria infection $(13,35)$. 
Acknowledgments. The authors acknowledge the assistance of Mary Joyce and Debbie Briggs in preparing the manuscript and J. Stoltz and P. Durnford for technical assistance.

\section{REFERENCES}

1. Bortolussi R, McGregor DD, Kongshavn PAL, Galsworthy S, Albritton W, Davis J, Seeliger HPR 1984 Host defense mechanisms to perinatal and neonatal Listeria monocytogenes infection. Surv Synth Path Res 3:311-332

2. Chen-Woan M, McGregor DD, Noonan SK 1986 Isolation and characterization of protective $\mathrm{T}$ cells induced by Listeria monocytogenes. Infect Immun 52:401-407

3. Chen-Woan M, McGregor DD, Goldschneider I 1984 Activation of Listeria monocytogenes-induced prekiller $\mathrm{T}$ cells by interleukin-2. Clin Invest Med 7:287-295

4. Havell EA, Spitalny GL, Patel PJ 1982 Enhanced production of murine interferon gamma by T-cells generated in response to bacterial infection. J Exp Med 156:112-127

5. Chen-Woan M, McGregor DD, Harris WV, Greiner DL 1986 Monoclonal antibody analysis of Listeria monocytogenes-induced cytotoxic lymphocytes. Immunology 57:505-513

6. Kaufmann SHE, Hug E, de Libero G 1986 Listeria monocytogenes-reactive T-lymphocyte clones with cytolytic activity against infected target cells. J Exp Med 164:363-368

7. Platsoucas CD 1986 Regulation of natural killer cytotoxicity by Escherichia coli-derived human interferon gamma. Scand $\mathrm{J}$ Immunol 24:93-108

8. Godfrey RW, Wilder MS 1984 Relationships between oxidative metabolism, macrophage activation, and antilisterial activity. J Leuk Biol 36:533-543

9. Harrington-Fowler L, Henson PM, Wilder MS 1981 Fate of Listeria monocy togenes in resident and activated macrophages. Infect Immun 33:11-16

10. Nakane A, Minagawa T, Yasuda I 1985 Induction of alpha/beta interferon and gamma interferon in mice infected with Listeria monocytogenes during pregnancy. Infect Immun 50:877-880

11. Nakane A, Minagawa T 1984 The significance of alpha/beta interferons and gamma interferon produced in mice infected with Listeria monocytogenes. Cell Immunol 88:29-40

12. Nakane A, Minagawa T 1981 Alternative induction of IFN-alpha and IFNgamma by Listeria monocytogenes in human peripheral blood mononuclear leukocyte cultures. J Immunol 126:2139-2142

13. Havell E 1986 Augmented induction of interferons during Listeria monocytogenes infection. J Infect Dis 153:960-969

14. Schreiber RD, Hicks LJ, Celada A, Bucheimer NA, Gray PW 1985 Monoclonal antibodies to murine gamma-interferon which differentially modulate macrophage activation and antiviral activity. J Immunol 134:1609-1618

15. Galleli A, LeGarrecord Y, Chedid L 1981 Increased resistance and depressed delayed-type hypersensitivity to $L$. monocytogenes induced by pretreatment with LPS. Infect Immun 31:88-94

16. Wakasugi N, Virelizier J-L, Arenzana-Seisdedos F, Rothhut B, Huerta J-MM Russo-Marie F, Fiers W 1985 Defective IFN-gamma production in the human neonate: II: role of increased sensitivity to suppressive effects of prostaglandin E. J Immunol 134:172-176

17. Wilson CB, Westall J, Johnston L, Lewis DB, Dower SK, Alpert AR 1986 Decreased production of interferon-gamma by human neonatal cells. J Clin Invest 77:860-867
18. Oh SH, Gonik B, Greenberg SB, Kohl S 1986 Enhancement of human neonata natural killer cytotoxicity to herpes simplex virus with use of recombinant human interferons; lack of neonatal response to interferon. J Infect Dis 153:791-795

19. Speer CP, Ambruso DR, Grimsley J, Johnson Jr. RB 1985 Oxidative metabolism in cord blood monocytes and monocyte-derived macrophages. Infect Immun 50:919-921

20. Bortolussi R, Campbell N, Krause V 1984 Dynamics of Listeria monocytogenes type $4 \mathrm{~b}$ infection in pregnant and infant rats. Clin Invest Med 7:273-279

21. Hawkins AE, Bortolussi R, Issekutz AC 1984 In vitro and in vivo activity of various antibiotics against Listeria monocytogenes type 4b. Clin Invest $\mathrm{Med}$ $7: 335-341$

22. Dijkema R, van der Meide PH, Pouwels PH, Caspers M, Dubbeld M, Schellekens $\mathrm{H} 1985$ Cloning and expression of the chromosomal immune interferon gene of the rat. EMBO J 4:761-767

23. Issekutz TB, Stoltz JM, van der Meide P 1988. Role of gamma-interferon in lymphocyte migration. Clin Exp Immunol 73:70-75

24. Mitsuyama M, Takeya K, Nomoto K, Shimotori S 1978 Three phases of phagocyte contribution to resistance against Listeria monocytogenes. J Gen Microbiol 106:165-171

25. McGregor DD, Chen-Woan M 1984 The cellular response to Listeria monocytogenes is mediated by a heterogeneous population of immunospecific $\mathrm{T}$ cells. Clin Invest Med 7:243-252

26. Weigent DA, Langford MP, Fleischmann WR Jr., Stanton GJ 1983 Potentiation of lymphocyte natural killing by mixtures of alpha or beta interferon with recombinant gamma interferon. Infect Immun 40:35-38

27. Buchmeier NA, Schreiber RD 1985 Requirement of endogenous interferongamma production for resolution of Listeria monocytogenes infection. Proc Natl Acad Sci USA 82:7404-7408

28. Kiderlen AF, Kaufmann SHE, Lohmann-Matthes M-L 1984 Protection of mice against the intracellular bacterium Listeria monocytogenes by recombinant immune interferon. Eur J Immunol 14:964-967

29. Pilaro AM, Laskin DL 1986 Accumulation of activated mononuclear phagocytes in the liver following lipopolysaccharide treatment of rats. J Leuk Biol 40:29-41

30. Burchett SK, Weaver WM, Westall JA, Larsen A, Kronheim S, Wilson CB 1988 Regulation of tumor necrosis factor/cachectin and IL-1 secretion in human mononuclear phagocytes. J Immunol 140:3473-3481

31. Hamilton RD, Wynalda MA, Fitzpatrick FA, Teagarden DL, Hamdy AH Snider BG, Weed SD, Stringfellow DA 1982 Comparison between circulating interferon and drug levels following administration of 2-amino-5-bromo-6phenyl-4(3H)-pyrimidinone (ABPP) to different animal species. $J$ Interf Res $2: 317-327$

32. Stringfellow DA 1981 Induction of interferon with low molecular weight compounds: fluorenone esters, ethers (tilorone), and pyrimidinones. Methods Enzymol 78:262-284

33. Anthony LS, Stevenson MM, Skamene E 1984 Enhancement of resistance to Listeria monocytogenes infection in mice by pyrimidine analogs. Clin Invest Med 7:343-348

34. Poindron P, Coupin G, Illinger D, Fauconnier B 1981 Induction of rat interferon in vivo and in vitro-physicochemical and biological characterization. Methods Enzymol 78:165-178

35. Nakane A, Minagawa T, Kato K 1988 Endogenous tumor necrosis factor (cachechtin) is essential to host resistance against Listeria monocytogenes infection. Infect Immun 56:2563-2569 